\title{
THE ROLE OF BCL-2 ONCOPROTEIN IN HEPATITIS C-RELATED HEPATOCELLULAR CARCINOMA
}

\author{
Gehan, M. Ibrahim, Shaden Muawia, Mohamed El-Shahat, and Tarek Kamel
}

Molecular biology Dept., Genetic engineering and biotechnology institute

University of Sadat City, Egypt

\begin{abstract}
Viral hepatitis has emerged as a major public health problem worldwide. There is increasing evidence that, several viral oncogenes such as core protein $\mathrm{C}$ virus $(\mathrm{HCV})$ is playing a direct role in neoplastic transformation. The tumor development requires both increased proliferation and inhibition of apoptosis. There is increasing experimental evidence to suggest that bcl-2 plays a critical role in blocking apoptosis in cancer cells. In the present study we tried to explore the role of bcl-2 in development of viral hepatitis into hepatocellular carcinoma (HCC). Out of 105 participants; 50 patients were HCV positive infected patients, 30 $\mathrm{HCC}$ patients either infected with $\mathrm{HCV}(\mathrm{HCC} / \mathrm{HCV})$ or not $(\mathrm{HCC})$ and 25 healthy volunteers were also included. We determined the serum level of bcl-2, AFP and HCV-RNA viral load in patients and compared them with the other clinicopathological parameters. Increased serum bcl-2 level was showed in $\mathrm{HCC} / \mathrm{HCV}$ infected patients more than HCV and controls $(P=0.001)$ and more than HCC patients $(P=0.018)$. A significant positive correlation between AFP and total load of viremia was elucidated $(r=0.345, P=0.014)$ in the HCV infected patients who didn't develop HCC. By analyzing the diagnostic performance of the studied parameters among the different groups. Bcl-2 was found to be a significant prognostic marker for the progression of HCC, as it represented two or more diagnostic values (Sensitivity $80 \%, 70 \%$ and specificity $60 \%, 70 \%$ respectively). and (OR=6.0, 95\% Cl=1.74-20.59\& OR=5.4 \& 95\% Cl=1.75-16.88). These results make bcl-2 a candidate marker for HCC progression following HCV infection in Egyptian patients.
\end{abstract}

Key words: Hepatocellular carcinoma (HCC) hepatitis C virus (HCV), bcl-2.

\section{INTRODUCTION}

Hepatocellular carcinoma (HCC) is a primary cancer of the liver that is predominant in developing countries, with nearly 600,000 deaths each year worldwide (El-Serag and Rudolph 2007). HCC normally develops as a consequence of underlying liver disease and is most often associated with cirrhosis (Blum 2005). Hepatitis C virus $(\mathrm{HCV})$ is now the major cause of chronic hepatitis, liver cirrhosis and hepatocellular carcinoma (HCC) in the western world. In addition, end-stage liver disease due to chronic hepatitis $C$ is the leading indication to liver transplantation (Williams 2006). It is estimated that 120-180 million people worldwide are infected with HCV (Shepard et al., 2005), which corresponds to roughly 4 times the number of individuals infected with HIV and about half the number of persons infected with the hepatitis $B$ virus (HBV). The seroprevalence rate is $1-2 \%$ in Western Europe and North America, $3-4 \%$ in some Mediterranean and Asian countries and up to $20 \%$ in Egypt and parts of Central Africa. (Stramer et al., 2004) Chronic hepatitis C virus (HCV) infection is characterized by inflammatory lesions in the liver, often accompanied by intrahepatic lipid accumulation (steatosis) and progressive fibrosis of variable degrees, and longterm progression to cirrhosis and hepatocellular carcinoma (HCC) (Moradpour and Blum, 2005; Zoulim et al., 2003). HCC incidence has increased sharply over recent decades and has been attributed to chronic HCV infection. Chronic $\mathrm{HCV}$ infection, therefore, is a major risk factor for HCC development. and HCV infection increases the risk for HCC development by an estimated 17fold compared to healthy individuals. (Donato et al., 2002; Imazeki et al., 2003; El-Serag 2002; Sun et al., 2003) HCV is the only RNA virus with a predominantly cytoplasmic life cycle. (Moradpour et al., 2007; Lindenbach et al., 2007) All potentially pro-oncogenic events are therefore likely to be restricted to the cytoplasm, suggesting indirect mechanisms of hepatocarcinogenesis. While HCV infection leads to chronic inflammation, steatosis, fibrosis and oxidative DNA damage, several HCV proteins have been shown to have direct oncogenic effects and to upregulate mitogenesis (McGivern et al., 2009; Koike 2007).

The anti-apoptotic factor B-cell leukemia /lymphoma $2 \mathrm{Bcl}-2$, is an oncogene in follicular lymphoma which is frequently linked to an immunoglobulin locus by the chromosome translocation (McGivern et al., 2009; Vaux et al., 
1988; Adams et al., 1998; Gross, et al., 1999). It was the first example of an oncogene that inhibits cell death rather than promoting proliferation. B cells transfected with bcl-2 were shown to be rendered resistant towards apoptosis induced by IL-3 withdrawal: for the first time it was shown that the pathway toward tumorigenesis depends not only on the ability to escape growth control but also depends on the ability to prevent apoptosis (16). The antiapoptotic bcl-2 family members are critical regulators of the mitochondrial apoptotic pathway that are not regulated by the cell surface receptor pathway or the "extrinsic pathway" (Adams et al., 1998; Gross, et al., 1999; Strasser et al., 1999).

For the early detection of sub clinical HCC by AFP measurement and/or ultra sonography (us) has been proposed since the 1980s. Some evidence also indicates that AFP secretion stimulates human hepatoma tumor cell growth and proliferation (Wang et al., 1999). Because the majority of cells losing the ability to silence AFP have a disease phenotype, it is likely that the mechanism by which AFP is re-activated is one way that HBV contributes to the development and progression of HCC.

AFP is a fairly specific but insensitive marker for HCC. Sensitivity of HCC detection by blood markers is improved by combining various other markers with AFP.

The cross relation between HCV proteins and host cell regulatory proteins was extensively studied, but still unable to clear the role of HCV in HCC initiation and/or progression. In this concern, the aim of the present work was to study the interference of the HCV infection in HCC patients with the serological markers trying to find out if there is any correlation with those markers in HCV infected patients and developing malignancy.

\section{PATIENTS AND METHODS}

Patients and grouping: This study was carried out on 105 participants. Eighty patients were recruited between January 2008 and March 2010 from Tropical medicine Department of Alexandria Main University Hospital, Egypt. Twenty five healthy volunteers were also included. This study was approved by the research review committee of the Alexandria faculty of Medicine. And all the studied subjects gave their informed consent. The studied subjects were classified into 3 main groups:- Group I included 50 HCV Positive patients 26 males and 24 females, their ages were ranged from 20 to 71 years old. Group II included $30 \mathrm{HCC}$ Patients who were further categorized into 2 subgroups (A\&B), subgroup $A$, included $20 \mathrm{HCC}$ patients infected with HCV 17 males and 3 females, their ages were ranged from 42 to 69 years old, and subgroup B, included 10
HCC patients who were HCV free 7 males and 3 females, their ages were ranged from 36 to 67 years old. In subgroup B, HCC developed due to Schistosomal infection, alcohol abuse or with unknown etiology rather than $\mathrm{HCV}$ infection. All subjects included in the study were negative for HBs Ag.

Group III is the Control group which included 25 healthy volunteers with matched age and sex were chosen carefully, the subjects of this group with no evidence of liver disease and who were negative for HCV antibodies. RT-PCR (Reverse transcription polymerase chain reaction) was performed for the first two groups to confirm HCV infection in group I and subgroup $A$ and absence of HCV infection in subgroup B.

\section{Methods:}

HCC patients were diagnosed by liver fine needle aspiration (Biopsy) whenever possible to confirm the presence of malignant tissues, or by ultrasonography and rectal snip.

All patients were subjected to:

A - Thorough history taking and clinical examination.

B - Laboratory investigations including:

1 - Liver function tests (Total Bilirubin, Albumin, Alanine amino transferase (ALT),

Aspartate amino transferase (AST), alkaline phosphatase and prothrombin time).

2 - Anti HCV antibodies (third generation) by microparticle enzyme immunoassay

(MEIA) technology on Axsym was performed for all participants. Positive cases Followed by RTPCR (Reverse transcription polymerase chain reaction) for estimation of total viremia.

3 - Quantitative determination of human serum bcl2.

4 - Quantitative determination of alpha-fetoprotein (AFP).

\section{Samples collection:}

Venous blood were withdrawn from all subjects, two $\mathrm{ml}$ was in vacutainer trisodium citrate tube for determination of prothrombin time $(\mathrm{PT})$, and the rest in a plain vacutainer tube, sample was allowed to clot for 30 minutes and then centrifuged at $3000 \mathrm{rpm}$. For 5 minutes, serum was stored in aliquots at $-20{ }^{\circ} \mathrm{C}$ for (Total bilirubin, Albumin, Alkaline phosphatase, ALT, AST, AFP and Bcl-2) determination.

Quantitative determination of a1-fetoprotein (AFP) using chemiluminescence technique on Cobas e 411 from Roche (Germany): (21)

Sandwich principle: $1^{\text {st }}$ incubation: $10 \mu \mathrm{l}$ of sample, a biotinylated monoclonal AFP-specific antibody, and monoclonal AFP-specific antibody labeled with a ruthenium complex (Tris(2.2bipyridyl) ruthenium (II). $2^{\text {nd }}$ incubation: After addition of streptavidin-coated microparticles, the 
complex becomes bound to the solid phase via interaction of biotin and streptavidin. The reaction mixture was aspirated into the measuring cell where the electrode. Unbound substances were then removed with procell. Application of a voltage to the electrode then induces chemiluminescent emission which was measured by a photomultiplier. Results were determined via a calibration curve which was instrument-specificity generated by 2-point calibration and a master curve provided via the reagent barcode.

Quantitative polymerase chain reaction (PCR) for HCV RNA (total viremia) by Real Time PCR (Taq Man Technology) by Step-One (Applied Biosystems): (22)

The TaqMan probe contains a fluorescent reporter dye at the 5 end of the probe and at the $3{ }^{`}$ end of the probe. When the probe was intact, the proximity of the reporter dye to the quencher dye suppresses the reporter fluorescence. Probe cleavage during the PCR reaction spatially separates the reporter dye from the quencher moiety and allows detection of the reporter dye fluorescence. Pathogen diagnosis by the polymerase chain reaction (PCR) was based on the amplification of specific regions of the pathogen genome. In real time PCR the amplified product was detected via fluorescent dyes. Monitoring the fluorescence intensities during the $\mathrm{PCR}$ run (i.e. in real time) allows the detection and quantitation of the accumulating product was allowed without having to re-open the reaction tubes after the run.

Bcl-2 Immunosorbent Assay: (23)
An anti-human bcl-2 Coating antibody is adsorbed onto microwells. Human bcl-2 present in the sample or standard binds to antibodies adsorbed to the microwells. A biotin-conjugated anti-human bcl-2 antibody was added and binds to human bcl-2.Captured by the first antibody. Following incubation unbound biotin-conjugated anti-human bcl-2 antibody was removed during a wash step. Streptavidin- HRP is added and binds to the biotin- conjugated anti-human $\mathrm{Bcl}-2$ antibody. Following incubation unbound Streptavidin-HRP was removed during a wash step, and substrate solution reactive with HRP was added to the wells.(Bender Med Systems, Austria).

Statistical analysis:

Statistical analysis was carried out using SPSS version 15. Values were expressed as mean $\pm S D$ Kruskal-Waills and Mann-Whitney tests were used. Pearson,s correlation was done between different parameters. ROC curve analysis was done and $\mathrm{X}^{2}$ was obtained by Chi-Square test. $\mathrm{P}$ is considered significant when $<0.05$

\section{RESULTS AND DISCUSSIONS}

One hundred and five individuals were enrolled in the study. With age ranged from 20-71 years. They were divided into 50 patients with $\mathrm{HCV}$ infection (54\% males, $46 \%$ females) 30 patients with hepatocellular carcinoma associated with $\mathrm{HCV}$ infection (HCC/HCV) (A) $(n=20)$ or non associated (HCC) (B) $(n=10)(85 \%$ males, $15 \%$ females and $70 \%$ males, $30 \%$ females respectively).Twenty five healthy individuals as a control group (68\% males, $32 \%$ females).

Table 1: Serum Bcl2, AFP, Total viremia levels and liver function tests among different studied groups.

\begin{tabular}{|c|c|c|c|c|c|c|}
\hline \multirow[t]{2}{*}{ Parameters } & \multirow{2}{*}{$\begin{array}{c}G I \\
\mathrm{HCV}(\mathrm{n}=50) \\
\mathrm{m} \pm \mathrm{SD}\end{array}$} & \multicolumn{2}{|c|}{ G II } & \multirow{2}{*}{$\begin{array}{c}\text { G III Control } \\
(n=25) \\
m \pm S D\end{array}$} & \multirow{2}{*}{$\begin{array}{l}\text { Test } \\
\text { Value } \\
\text { (F) }\end{array}$} & \multirow{2}{*}{$\begin{array}{l}\text { Over } \\
\text { all } P \\
\text { value }\end{array}$} \\
\hline & & $\begin{array}{c}\mathrm{A}(\mathrm{HCC} / \mathrm{HCV}) \\
(\mathrm{n}=20) \\
\mathrm{m} \pm \mathrm{SD}\end{array}$ & $\begin{array}{l}\mathrm{B}(\mathrm{HCC}) \\
(\mathrm{n}=10) \\
\mathrm{m} \pm \mathrm{SD}\end{array}$ & & & \\
\hline Age(yr) & $51.02 \pm 12.85$ & $56.70 \pm 7.6$ & $54.80 \pm 9.46$ & $53.68 \pm 13.81$ & $1.184^{b}$ & 0.320 \\
\hline $\begin{array}{c}\mathrm{Bcl}- \\
2(\mathrm{ng} / \mathrm{ml})\end{array}$ & $3.77 \pm 5.18$ & $13.74 \pm 15.61$ & $2.41 \pm 1.15$ & $2.07 \pm .60$ & $15.55^{a}$ & 0.001 \\
\hline $\mathrm{AFP}(\mathrm{ng} / \mathrm{ml})$ & $8.56 \pm 12.79$ & $3671.04 \pm 5044.1$ & $3790.40 \pm 5262.81$ & $2.40 \pm .73$ & $75.24^{a}$ & $<0.001$ \\
\hline $\begin{array}{c}\text { viremia } \\
\text { (copies } / \mathrm{ml} \text { ) }\end{array}$ & $530 \pm 860$ & $1367 \pm 778$ & ------- & -------- & ------- & $<0.001$ \\
\hline AST (U/L) & $58.62 \pm 45.66$ & $102.10 \pm 49.48$ & $107.2 \pm 50.64$ & $28.56 \pm 6.7$ & $44.16^{a}$ & $<0.001$ \\
\hline $\mathrm{ALT}(\mathrm{U} / \mathrm{L})$ & $58.12 \pm 43.18$ & $60.80 \pm 24.01$ & $69.00 \pm 32.02$ & $26.48 \pm 7.42$ & $29.82^{a}$ & $<0.001$ \\
\hline $\begin{array}{c}\text { Albumin } \\
(\mathrm{g} / \mathrm{dl})\end{array}$ & $3.57 \pm .49$ & $2.97 \pm .54$ & $3.14 \pm .42$ & $4.05 \pm .40$ & $21.76^{b}$ & $<0.001$ \\
\hline PT(Sec.) & $13.06 \pm 1.51$ & $16.00 \pm 3.13$ & $14.36 \pm 2.19$ & $11.38 \pm .33$ & $24.69^{b}$ & $<0.001$ \\
\hline $\begin{array}{c}\text { Bilirubin } \\
(\mathrm{mg} / \mathrm{dl})\end{array}$ & $1.04 \pm .36$ & $2.41 \pm 2.99$ & $4.87 \pm 5.60$ & $0.60 \pm .07$ & $55.43^{\mathrm{a}}$ & $<0.001$ \\
\hline $\begin{array}{c}\text { Alk. } \\
\text { Phosph. } \\
\text { (U/L) }\end{array}$ & $238.66 \pm 85.92$ & $477.15 \pm 262.00$ & $454.4 \pm 126.83$ & $172.68 \pm 59.29$ & $55.79^{a}$ & $<0.001$ \\
\hline
\end{tabular}

(a) Significant difference between 2 groups.

(b) Significant difference between more than 2 groups. 
Serum levels of all serological parameters were represented in figures 1, 2 .

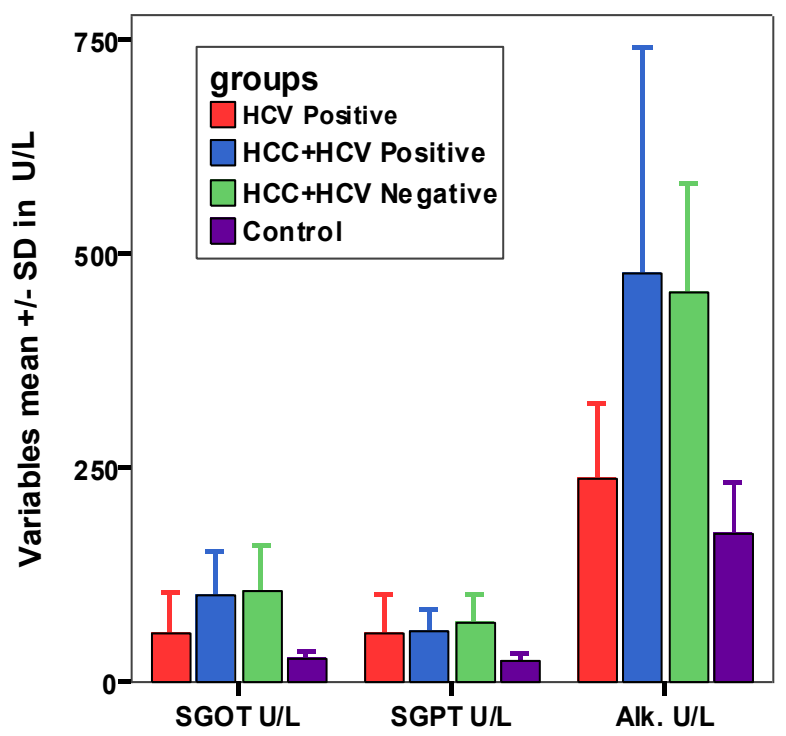

Figure 1: comparison of the mean values of SGOT ,SGPT and alkline phosphatase among different studied groups.

Bcl-2 level was highly significant elevated in $\mathrm{HCC} / \mathrm{HCV}$ than $\mathrm{HCV}$ infected patients and control $(P=0.001)$ besides it's significantly elevated in comparison to HCC patients $(P=0.018)$.

The level was non significantly elevated in HCV and HCC compared to control or between each other. (Table 1)

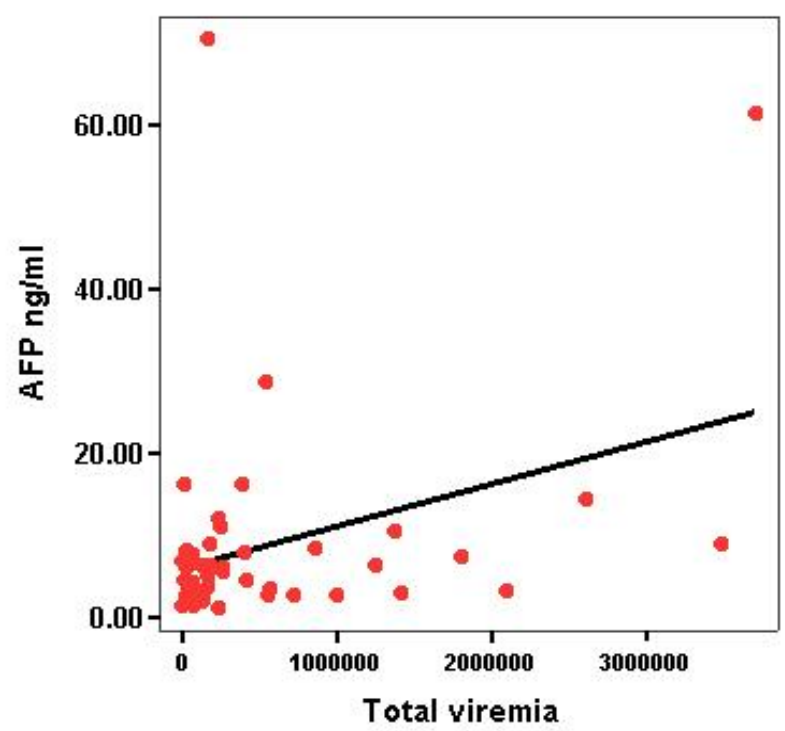

Figure 3: Correlation between Alpha feto protein and total viremia in $\mathrm{HCV}$ positive group $(\mathrm{r}=0.345$, $\mathrm{P}=0.014$ )

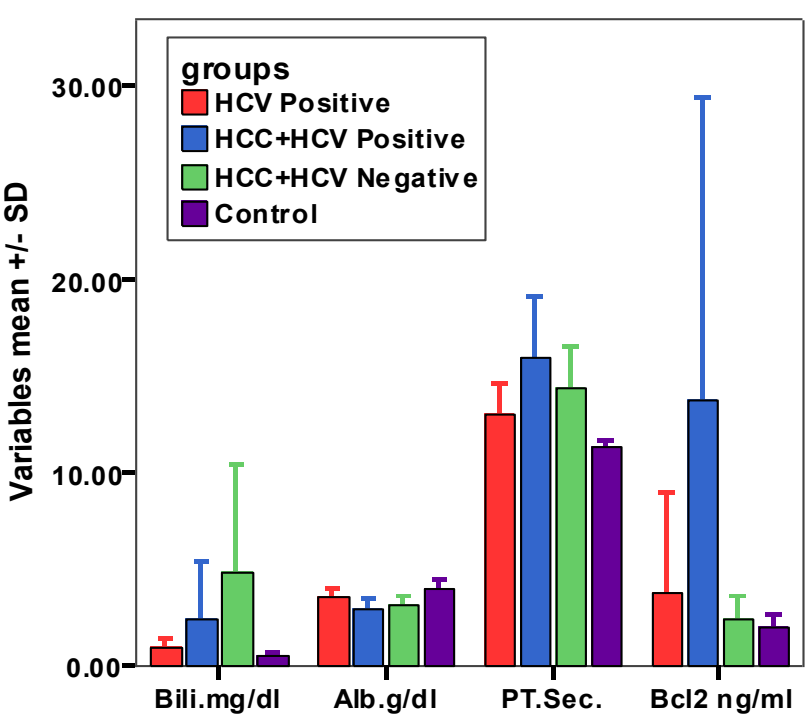

Figure 2: comparison of the mean values of Bilirubin, albumin, prothrombin and bcl2 among different studied groups.

AFP and total viremia were significantly correlated in $\mathrm{HCV}$ infected patients $(\mathrm{P}=0.014)$.

AFP was also significantly correlated with albumin and bilirubin in the same group $(P=0.031$, $\mathrm{P}=0.059$ ) respectively. As shown in figures $3,4,5$.

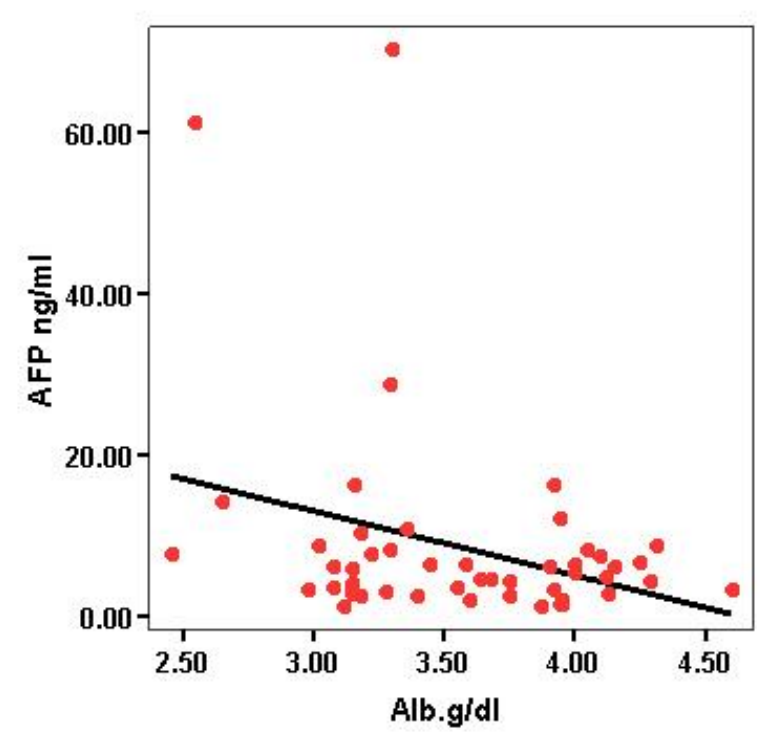

Figure 4: Correlation between Alpha feto protein and albumin in $\mathrm{HCV}$ positive group $(\mathrm{r}=-0.305, \mathrm{P}=0.031)$ $\mathrm{P}=0.031$ ) 


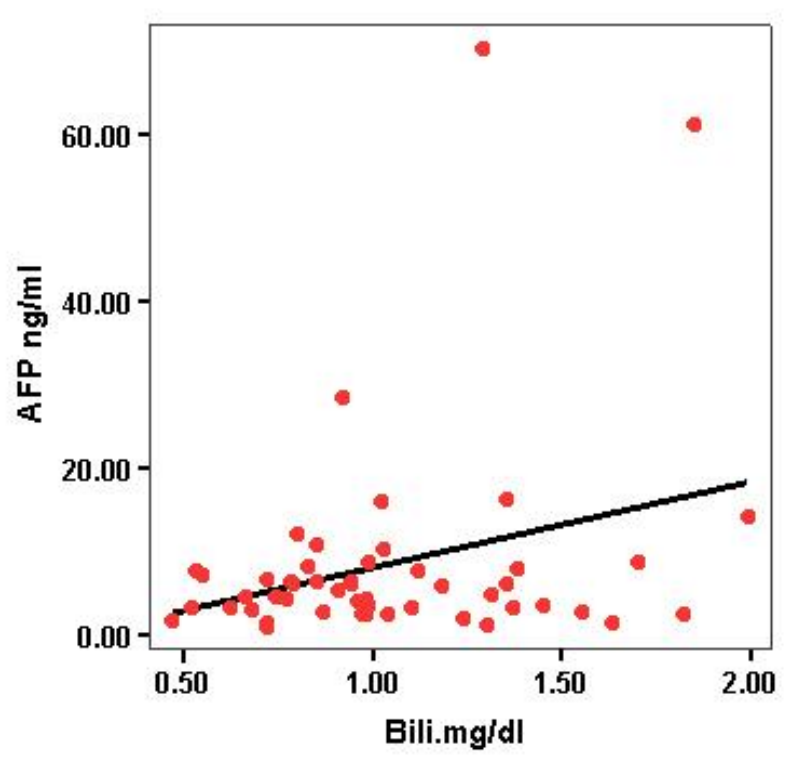

Figure 5: Correlation between Alpha feto protein and bilirubin in HCV positive group ( $\mathrm{r}=0.294$, $\mathrm{P}=0.039$ ).

While in HCC/HCV patients AFP was significantly correlated to alkaline phosphatase enzyme and bilirubin as represented in figures 6,7 .

Total viremia was in a negative significant correlation with prothrombin time in $\mathrm{HCC} / \mathrm{HCV}$ patients $(P=0.020)$ (figure 8$)$.

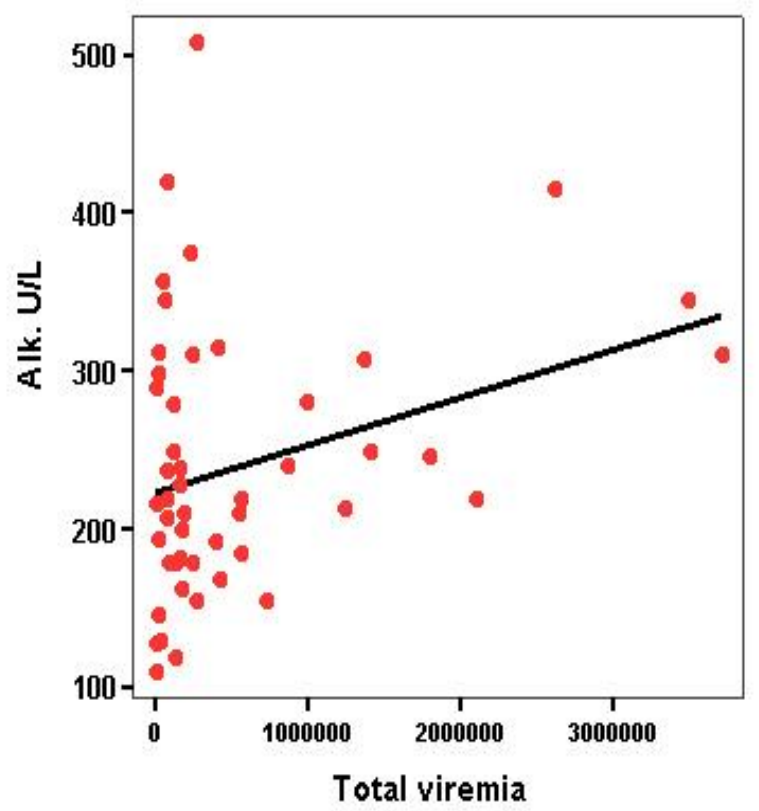

Figure 7: correlation between alkaline phosphatase and total viremia in $\mathrm{HCC}+\mathrm{HCV}$ positive group $(\mathrm{r}=-0.226, \mathrm{p}=0.339)$

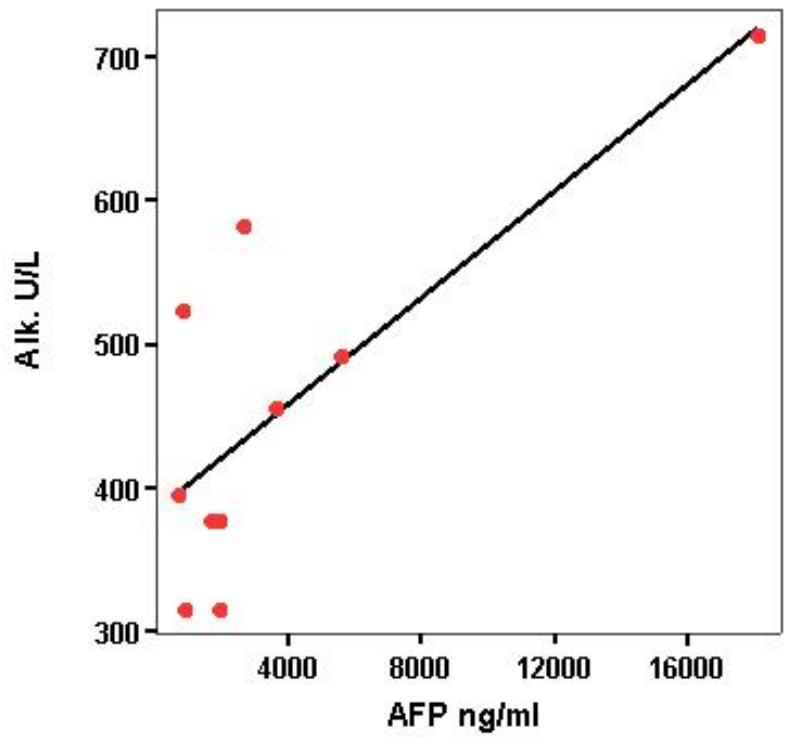

Figure 6: Correlation between Alpha feto protein and alkaline phosphatase in $\mathrm{HCC}+\mathrm{HCV}$ negative group $(\mathrm{r}=0.769$ $\mathrm{P}=0.009$ ).

While it was significantly correlated with bilirubin and alkaline phosphatase in $\mathrm{HCV}$ infected patients $(P=0.002, P=0.034)$ (figures 9,10$)$.

While bcl2, was not significantly correlated with other parameters in all patients groups.

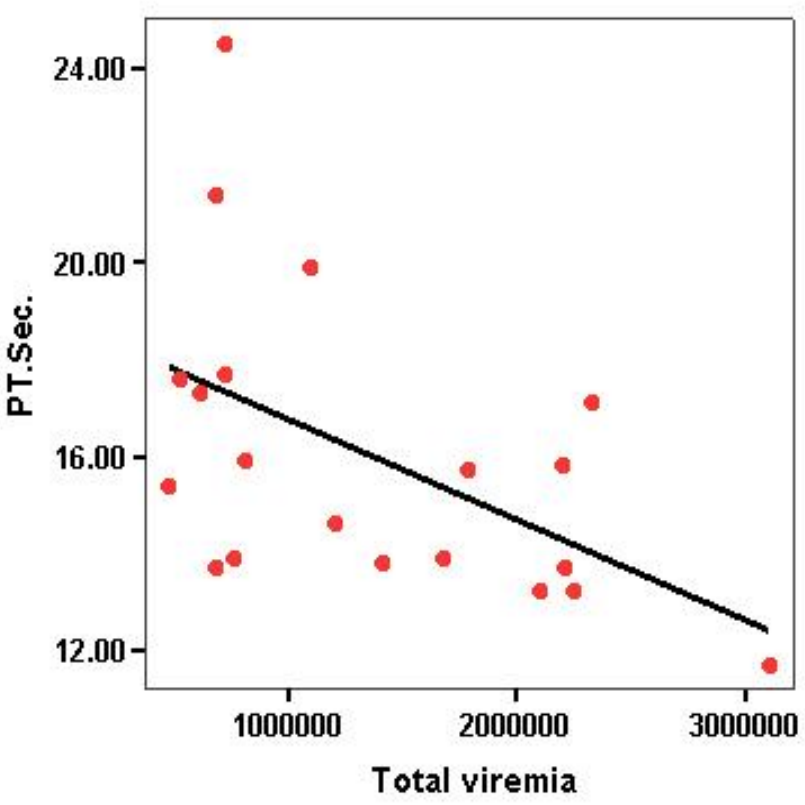

Figure 8: Correlation between prothrombin time and total vairemia in $\mathrm{HCC}+\mathrm{HCV}$ positive group $(\mathrm{r}=$ $-0.516, p=0.020$ ) 


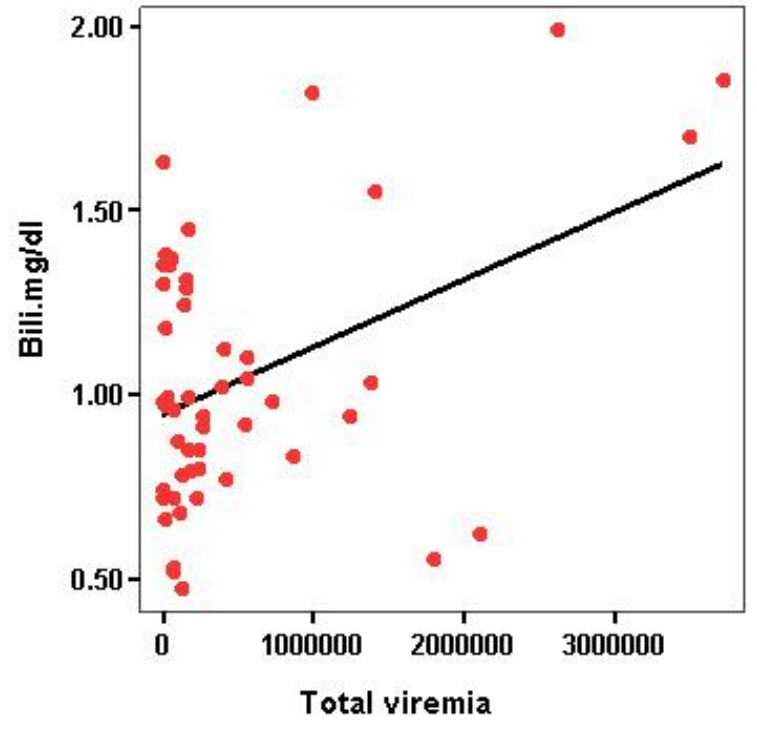

Figure 9: Correlation between bilirubin and total viremia In $\mathrm{HCV}$ positive group $(\mathrm{r}=-0.432$, $\mathrm{P}=0.002$ )

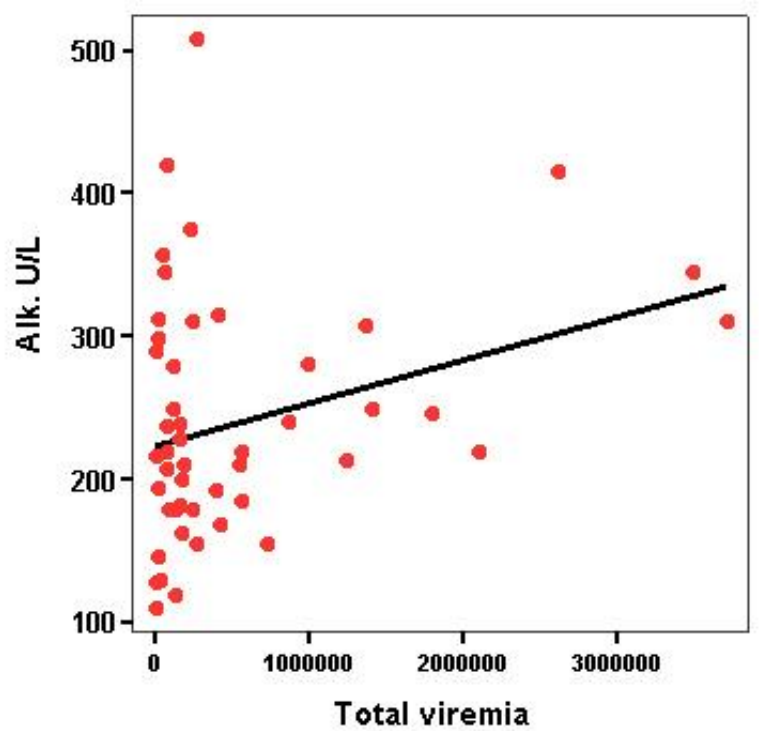

Figure 10: Correlation between alkaline phosphatase and total vairemia

In $\mathrm{HCV}$ positive group $(\mathrm{r}=-0.300$, $\mathrm{P}=0.034)$

Table 2: Correlation of Bcl-2, AFP levels and total viremia in HCV infected patients.

\begin{tabular}{|c|c|c|c|c|c|c|}
\hline \multirow{2}{*}{ Parameters } & \multicolumn{2}{|c|}{ BCL-2 } & \multicolumn{2}{c|}{ AFP } & \multicolumn{2}{c|}{ Total viremia } \\
\cline { 2 - 7 } & $\mathrm{r}$ & $\mathrm{P}$ & $\mathrm{r}$ & $\mathrm{P}$ & $\mathrm{r}$ & $\mathrm{P}$ \\
\hline BCL-2 & 1 & - & 0.084 & 0.562 & -0.047 & 0.747 \\
\hline AFP & 0.084 & 0.562 & 1 & - & 0.345 & 0.014 \\
\hline Total viremia & -0.047 & 0.747 & 0.345 & 0.014 & 1 & - \\
\hline Age & -0.005 & 0.974 & 0.150 & 0.297 & 0.198 & 0.168 \\
\hline AST & 0.058 & 0.691 & 0.096 & 0.506 & 0.063 & 0.666 \\
\hline ALT & 0.018 & 0.900 & -0.072 & 0.620 & 0.128 & 0.374 \\
\hline Albumin & -0.011 & 0.940 & -0.0305 & 0.031 & -0.078 & 0.590 \\
\hline PT & -0.048 & 0.742 & 0.033 & 0.823 & 0.195 & 0.175 \\
\hline Bilirubin & 0.217 & 0.129 & 0.294 & 0.039 & 0.432 & 0.002 \\
\hline Alk. phosphatase & -0.150 & 0.298 & 0.089 & 0.538 & -0.300 & 0.034 \\
\hline
\end{tabular}

Table 3: Correlation of Bcl-2, AFP levels and total viremia in HCC/HCV patients.

\begin{tabular}{|c|c|c|c|c|c|c|}
\hline \multirow{2}{*}{ Parameters } & \multicolumn{2}{|c|}{ BCL-2 } & \multicolumn{2}{c|}{ AFP } & \multicolumn{2}{c|}{ Total viremia } \\
\cline { 2 - 7 } & $\mathrm{r}$ & $\mathrm{P}$ & $\mathrm{r}$ & $\mathrm{P}$ & $\mathrm{r}$ & $\mathrm{P}$ \\
\hline BCL-2 & 1 & - & -0.253 & 0.282 & -0.137 & 0.564 \\
\hline AFP & -0.253 & 0.282 & 1 & - & 0.057 & 0.810 \\
\hline Total viremia & -0.137 & 0.564 & 0.057 & 0.810 & 1 & - \\
\hline Age & 0.289 & 0.217 & -0.328 & 0.159 & -0.305 & 0.191 \\
\hline AST & 0.232 & 0.325 & -0.135 & 0.571 & 0.007 & 0.976 \\
\hline ALT & 0.094 & 0.693 & 0.095 & 0.690 & -0.161 & 0.497 \\
\hline Albumin & 0.258 & 0.272 & 0.255 & 0.278 & 0.258 & 0.272 \\
\hline PT & -0.150 & 0.527 & -0.258 & 0.273 & -0.516 & 0.020 \\
\hline Bilirubin & 0.111 & 0.641 & -0.250 & 0.289 & 0.253 & 0.281 \\
\hline Alk. phosphatase & 0.234 & 0.321 & 0.433 & 0.056 & -0.226 & 0.339 \\
\hline
\end{tabular}


Table 4 : Correlation of Bcl-2, AFP levels and total viremia in HCC patients

\begin{tabular}{|c|c|c|c|c|}
\hline \multirow{2}{*}{ Parameters } & \multicolumn{2}{|c|}{ BCL-2 } & \multicolumn{2}{c|}{ AFP } \\
\cline { 2 - 5 } & $\mathrm{r}$ & $\mathrm{P}$ & $\mathrm{r}$ & $\mathrm{P}$ \\
\hline BCL-2 & 1 & 0.225 & 1 & 0.225 \\
\hline AFP & 0.422 & 0.112 & -0.005 & 0.990 \\
\hline Age & 0.534 & 0.823 & 0.054 & 0.882 \\
\hline AST & -0.081 & 0.742 & 0.225 & 0.531 \\
\hline ALT & -0.120 & 0.933 & -0.333 & 0.347 \\
\hline Albumin & -0.031 & 0.210 & 0.240 & 0.504 \\
\hline PT & 0.434 & 0.196 & 0.911 & 0.000 \\
\hline Bilirubin & 0.446 & 0.578 & 0.769 & 0.009 \\
\hline Alk. phosphatase & 0.201 & & \\
\hline
\end{tabular}

Receiver Operating Characteristic (ROC) Curve analysis (figure 11):

ROC curve analysis was designed for BCL-2 in $\mathrm{HCV}$ infected patients against $\mathrm{HCC} / \mathrm{HCV}$ group of patients Roc curve was performed as cut off for disease progression. The area under the curve and the best cut off values (c.o.v.) and youden index of bcl-2 levels were obtained from the sensitivity and specificity \% in progression of malignancy (24).

The ROC curve analysis showed that BCL-2 presented a significant area under the curve of
0.765 and achieved sensitivity (80\%, 75\%, 70\%) and specificity $(60 \%, 68 \%, 70 \%)$ respectively. Table 5: represented the risk estimate at different relative bcl-2 cut off values $(2.19,2.67,2.76)$, after calculating the positive and negative predictive values corresponding to each cut off.

A significantly elevated relative risk by $5.4-6.3$ folds more for developing malignancy after HCV infection

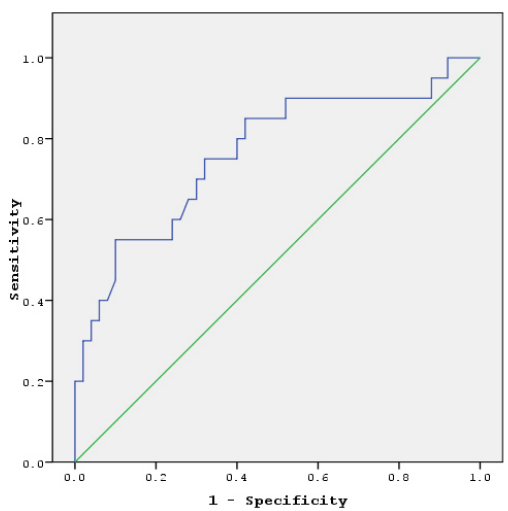

Figure 11 : Different diagnostic values of $\mathrm{Bcl}-2$ obtained from ROC curve

\begin{tabular}{|c|c|c|c|c|c|c|}
\hline $\begin{array}{l}\text { Biochemical } \\
\text { parameter }\end{array}$ & $\begin{array}{l}\text { ROC } \\
\text { Area under the } \\
\text { curve }\end{array}$ & Sig & $\begin{array}{l}\text { Youden's } \\
\text { index }\end{array}$ & Sensitivity & 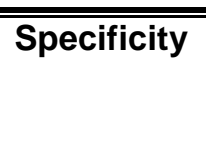 & $\begin{array}{l}\text { Cut } \\
\text { off } \\
\text { Value }\end{array}$ \\
\hline \multirow[t]{3}{*}{ Bcl2 } & \multirow[t]{3}{*}{0.765} & \multirow[t]{3}{*}{0.001} & 0.40 & $80 \%$ & $60 \%$ & $\begin{array}{l}\geq \\
2.19\end{array}$ \\
\hline & & & 0.43 & $75 \%$ & $68 \%$ & $\geq 2.67$ \\
\hline & & & 0.40 & $70 \%$ & $70 \%$ & $\geq 2.76$ \\
\hline
\end{tabular}


Table 5: Frequency distribution and risk estimate at different bcl-2 cut off values in HCV infected patients and $\mathrm{HCC} / \mathrm{HCV}$ patients.

\begin{tabular}{|c|c|c|c|c|c|c|c|}
\hline Group & $\begin{array}{l}\text { BCL-2 } \\
\text { cut off } \\
\text { value }\end{array}$ & $\begin{array}{c}+\mathrm{ve} \\
\text { predictive } \\
\text { value }\end{array}$ & $\begin{array}{c}\text {-ve } \\
\text { predictive } \\
\text { value }\end{array}$ & $\mathrm{X}^{2}$ & OR & $95 \% \mathrm{Cl}$ & $\mathbf{P}$ \\
\hline HCV & \multirow{3}{*}{$\geq 2.19$} & 20 (40\%) & $30(60 \%)$ & & & & \\
\hline & & & & 9.150 & 6.000 & $1.748-20.591$ & 0.002 \\
\hline $\mathrm{HCC} / \mathrm{HCV}$ & & $16(80 \%)$ & $40(20 \%)$ & & & & \\
\hline $\mathrm{HCV}$ & \multirow{3}{*}{$\geq 2.67$} & $16(32 \%)$ & $34(68 \%)$ & & & & \\
\hline & & & & 10.7 & 6.375 & $1.971-20.615$ & 0.001 \\
\hline $\mathrm{HCC} / \mathrm{HCV}$ & & $15(75 \%)$ & $5(25 \%)$ & & & & \\
\hline $\mathrm{HCV}$ & \multirow{3}{*}{$\geq 2.76$} & $15(30 \%)$ & 35 (70\%) & & & & \\
\hline & & & & 9.420 & 5.444 & $1.756-16.881$ & 0.002 \\
\hline $\mathrm{HCC} / \mathrm{HCV}$ & & $14(70 \%)$ & $6(30 \%)$ & & & & \\
\hline
\end{tabular}

$X^{2}$ : obtained by chi-square test. $P$ : is considered significant $<0.05$ OR : odds ratio, $, 95 \% \mathrm{Cl}: 95 \%$ confidance interval

HCV-associated hepatocellular carcinoma is a common neoplasm in Egypt. Since tumor development requires both increased proliferation and inhibition of apoptosis; HCC was exclusively related to HCV infection. bcl-2 gene is known to provide a survival advantage to rapidly proliferating cells. Physiologically bcl-2 protein blocks the apoptotic process by inhibiting the release of cytochrome $C$ from mitochondria whereas it locates at the cytoplasmic surface of mitochondrial membrane, nuclear membrane and endoplasmic reticulum (Brown 1997).

Chung $Y \mathrm{~L}$ and his team (Chung et al., 2003) stated that HCV mimics the effect of bcl-2 and maintains the growth of $\mathrm{HCC}$, where the nonstructural 5A (NS5A) protein of hepatitis $C$ virus region contains three bcl-2 homology domains $(\mathrm{BH} 3, \mathrm{BH} 1, \mathrm{BH} 2)$ which can interact with Bax and lead to the inhibition of apoptosis.

The present work aimed to assess whether HCV infection in HCC patients affects the levels of bcl-2 in comparison to non-infected HCC patients and HCV patients who didn't develop HCC the data revealed that bcl-2 level is influenced by HCV infection, as it is up regulated whenever HCV infection is developed into HCC. The diagnostic performance of bcl-2 estimated an increased risk by 5-6 folds more for developing HCC after HCV infection. Bcl-2 appeared to be over expressed in patients with $\mathrm{HCV} / \mathrm{HCC}$ patients compared to those with chronic hepatitis and HCC-non associated HCV. It suggests that bcl-2 may have a role in development or progression of HCC in patients with chronic hepatitis C. It was not correlated with total viremia or AFP or ALT levels in all patient groups either infected with HCV or not. Our data indicated that total viremia is related to AFP and bilirubin serum level in patients with chronic hepatitis $\mathrm{C}$. This finding correlates with the previous reports (Sultan et al., 2006) which stated that high viral load associated frequently with HCC in patients with HCV. A study by Sultan. et al. reported that although there is a significant increase in the bcl-2 level in HCC patients associated with HCV infection compared to HCC patients alone, the results suggest that HCV might not be the direct cause of bcl-2 elevation, since not all HCV-infected patients had increased level of bcl-2. Previous reports have indicated that the expression of bcl-2 mRNA was up regulated in HCC, but low level of bcl-2 protein was detected (Ravazoula et al., 2002).

A contradictory study by Vail and his coworkers (Vail et al., 2001) postulated that bcl-2 does not play a role in the progression of HCC in patients with progressive tumors (GII and G III). While, another study (Chung et al., 2003) found that in HCC patients with GI a significant relation ship between bcl-2 protein in HCV infected and HCVfree patients. It is speculated that HCV may exert an anti-apoptotic effect and thus enhance tumorigenesis. A previous study (Ali et al., 2004) revealed a positive correlation between bcl-2 and AFP in HCC patient infected with HCV concluding 
that the increased level of bcl-2 in HCC may be involved in hepatocarcinogenesis.

A recent study (Alenzi et al., 2010) was done on Egyptian patients with chronic $\mathrm{HCV}$ infection either developed HCC or not. As they evaluated the expression of bcl-2 by ELISA, Their results were in some way in a good agreement with ours, as bcl-2 level increased in $\mathrm{HCV}$ patients who developed HCC. They collectively concluded that Apoptosis is dysregulated and proliferation activity perturbed. In the present study, bcl-2 protein expression showed a dramatical highly significant increase in HCV patients who developed HCC, in comparison to other groups $(P=0.001)$. Over expression of bcl-2 gene could lead to apoptosis inhibition and enable cell survival (Anatol et al., 2005).

A study by Hamazaki and co-workers (Hamazaki et al., 1995) in Japan was done to examine the expression of Fas antigen and bcl-2 protein in normal liver, diseased liver (chronic hepatitis or liver cirrhosis) and HCC. They found a difference in bcl-2 expression among the groups, but it was not significant. They suggested the induction of apoptosis may be a possible therapy against HCC. The conflict here is that in the present study, the Over-expression of bcl-2 in $\mathrm{HCV}$ patients who developed HCC was much higher than the bcl-2 up regulation in HCC patients without HCV infection (almost the same like the characteristics of HCC group in Hamazaki K. et al. (Hamazaki et al., 1995). This provided us to use $\mathrm{HCV}$ infection and bcl-2 related expression as a control arm to predict developing HCC.

The diagnostic performance of the Roc curve, in the present study, by examining the different studied parameters; revealed that bcl-2 was found to be a significant prognostic marker for the progression of $\mathrm{HCC}$ associated with $\mathrm{HCV}$ infection (sensitivity $70-80 \%$ and specificity $68-70 \%$ ). This finding makes bcl-2 beside AFP; are good markers for detecting the progression of hepatocellular carcinoma after HCV infection.

Conclusions: The results in the present study predict a significant role of $\mathrm{HCV}$ infection on the circulating bcl-2 protein in both $\mathrm{HCV}$ and $\mathrm{HCC} / \mathrm{HCV}$ patients. Bcl-2 could be a candidate marker for HCC progression following HCV infection. Bcl-2 determination may play a significant role in diagnosis, monitoring therapy, and evaluating malignant progression in HCV infected patients.

\section{REFERENCES}

Adams, J. M. and Cory, S. The Bcl-2 protein family: arbiters of cell survival. Science (1998); 281, 1322-1326.

Alenzi F. Q. , El-Nashar E. M. , Al-Ghamdi S. S. , Abbas M. Y. , Hamad A. M. ,El-Saeed O. M. ,
Wyse R. K. H. , Lotfy M. Investigation of Bcl2 and PCNA in Hepatocellular Carcinoma: Relation to Chronic HCV. Journal of the Egyptian Nat. Cancer Inst., (2010), 22, (1): 87-94.

Ali M. A. , Koura B. A. , El-Mashad N. and Zaghloul M. H. The Bcl-2 and TGF-B1 levels in patients with chronic hepatitis $\mathrm{C}$, liver cirrhosis and hepatocellualr carcinoma. The Egyptian Journal of Immunology. (2004), 11 (1) : 83-90.

Anatol $\mathrm{P}$, Danuta $\mathrm{P}$, Janusz $\mathrm{D}$, Bozena $\mathrm{P}$. Expression of bcl-2 protein in chronic hepatitis $\mathrm{C}$ : Effect of interferon alpha $2 \mathrm{~b}$ with ribavirin therapy. World J Gastroenterol. (2005), 11 (19): 2949-52.

Barbareschi M,Caffo. Veronese S, Leek RD, Fina P, Fox S, Bonzanini M, Girlando S, Morelli L, Eccher C, Pezzella F, Doglioni C, Palma PD, Harris A, Bcl-2 and P53 expression in nodenegative breast carcinoma- a study with longterm follow-up. Human Pathology. , (1996); 27(11):1149-1155.

Blum H. Hepatocellular carcinoma: therapy and prevention. World JGastroenterol (2005);11:7391-7400.

Brown R. The bcl-2 family of proteins. $\mathrm{Br}$ Med Bull (1997); 53 : 466-77.

Chung YL, Sheu ML,Yen SH. Hepatitis C virus NS5A as potential viral Bcl-2 homologue interacts with Bax and inhibits apoptosis in hepatocellular carcinoma. Int $\mathrm{J}$ Cancer. (2003); 107:65-73.

Donato F, Tagger A, Gelatti U, Parrinello G, Boffetta $P$, Albertini A, et al. Alcohol and hepatocellular carcinoma: the effect of lifetime intake and hepatitis virus infections in men and women. Am $J$ Epidemiol (2002);155:323-331.

El-Serag HB, Rudolph KL. Hepatocellular carcinoma: epidemiology and molecular carcinogenesis. Gastroenterology (2007);132:2557-2576.

El-Serag HB. Hepatocellular carcinoma: an epidemiologic view. J Clin Gastroenterol (2002);35:S72-S78.

Gross, A., McDonnell, J. M., and Korsmeyer, S. J. BCL-2 family members and the mitochondria in apoptosis. Genes Dev. (1999); 13, 1899- 1911.

Hamazaki K., Gochi A. , Matsubara N. , Mori M. , Orita K. Expression of Fas antigen and Bcl-2 protein in hepatocellular carcinoma. Actamedica Okayama.(1995), 49(4): 227230.

Hilden J.,Glaziou P.,Regret graphs-diagnostic uncertainty and Youden index,Statistics in medicine,15,1996,969-86.

Imazeki F, Yokosuka O, Fukai K, Saisho $\mathrm{H}$. Favorable prognosis of chronic hepatitis C 
after interferon therapy by long-term cohort study. Hepatology (2003);38:493-502.

Koike K. Pathogenesis of HCV-associated HCC: Dual-pass carcinogenesis through activation of oxidative stress and intracellular signaling. Hepatol Res (2007);37:S115-S120

Lindenbach BD, Thiel HJ, Rice CM. Flaviviridae: the viruses and their replication. In: Knipe DM, Howley PM, editors. Fields virology, 5th ed. Philadelphia: Lippincott-Raven Publishers; (2007).

McGivern DR, Lemon SM. Tumor suppressors, chromosomal instability, and hepatitis C virus-associated liver cancer. Annu Rev Pathol (2009);4:399-415.

Moradpour D, Blum HE. Pathogenesis of hepatocellular carcinoma. Eur J Gastroenterol Hepatol (2005);17:477-483.

Moradpour D, Penin F, Rice CM. Replication of hepatitis C virus. Nat Rev Microbiol (2007);5:453-463.

Ravazoula P, Tsamandas AC, Kardamakis D, Gogos C, Karatza C, Thomopoulos K, Tepetes K, Kourelis T, Petsas T, Bonikos DS, Karavias D. The potential role of bcl-2 mRNA and protein expression in hepatocellular carcinomas. Anticancer Res (2002); 22:1799805.

Sato $\mathrm{Y}$, et al. Early recogontion of hepatocellular carcinoma based on altered profiles of alphafetoprotein. New Engl J Med 1993;328,25:1802-1806.

Shepard C.W., Finelli L., Alter M. J. Global epidemiology of hepatitis $C$ virus infection. Lancet Infect Dis (2005); 5:558-567.
Stramer S. L., Glynn S.A, Kleinman S. H., Strong D. M., Sally C., Wright D. J., et al. Detection of HIV-1 and HCV infections among antibody-negative blood donors by nucleic acid-amplification testing. $\mathrm{N}$ Engl J Med (2004); 351:760-768.

Strasser, A., Harris, A. W., Huang, D. C., Krammer, P. H., and Cory, S. Bcl-2 and Fas/APO-1 regulate distinct pathways to lymphocyte apoptosis. EMBO J. (1995);14, 6136-6147.

Sultan A. S., Saad E., Hessien M., Mahmoud E., Ibrahim A. M., Sherif Z. A. Molecular markers of hepatitis $C$ virus-related hepatocellualr carcinoma. Cancer Biology \& Therapy. (2006), 5:6 , 623-629.

Sun CA, Wu DM, Lin CC, Lu SN, You SL, Wang $L Y$, et al. Incidence and cofactors of hepatitis $C$ virus-related hepatocellular carcinoma: a prospective study of 12,008 men in Taiwan. Am J Epidemiol (2003);157:674-682.

Vail ME, Pierce RH, Fausto N. Bcl-2 delays and alters hepatic Carcinogenesis induced by transforming growth factor alpha. Cancer Res (2001); 61:594-601.

Vaux, DL, Cory, S and Adams, JM."Bcl-2 gene promotes haemopoietic cell survival and cooperates with c-myc to immortalize pre-B cells." Nature (1988);335(6189): 440-2.

Wang, $X$ W.Role of P53 and apoptosis in carcinogenesis. Anticancer Res (1999);19(6A) : 4759-71.

Williams R. Global challenges in liver disease. Hepatology 2006; 44:521-526.

Zoulim F, Chevallier M, Maynard M, Trepo C. Clinical consequences of hepatitis $C$ virus infection. Rev Med Virol (2003);13:57-68. 